\title{
A Traveler's-Eye View of Libraries in the Near East
}

Miss Frick is assistant professor of library service, Columbia University.

$\mathrm{E}$

ARLY IN 1948 I was given a sevenmonth sabbatical leave for travel abroad. Although half of the time was spent in various European countries, this paper concerns my tour of the Near and Middle East. My real reason for traveling to those parts was to visit the lands whose civilization had produced the oldest books in the world and the largest libraries of antiquity; to see the region which had evolved the alphabet and where still remains the oldest alphabetic inscription extant; and to climb the famous Behistun Rock in Iran, whose trilingual record had furnished the key to the deciphering of cuneiform script. My way began at Alexandria, and after going up and down the Nile I crossed the Mediterranean to visit Syria, Trans-Jordan, Iraq and Iran.

Whenever time permitted and fancy dictated, I visited libraries in a casual way just as one drops into a library when making a short stay in an American town. In none of them did I present a letter of introduction-only my personal visiting card -nor proceed according to organized plan. In all of them I met with friendly courtesy, intelligence and a respect for American librarianship which was truly touching. These random remarks are impressions of some of the situations which interested me.

The "Vulcania" had Alexandria as its port of call and most of its Egypt-bound passengers hurried to Cairo as fast as the train could carry them. Even though I knew very well that not a trace of the glory of the huge libraries of the Ptolemies remained - that doubt exists even as to their exact location-I could not resist lingering in Alexandria to tread the ground and see the sites where the immortal Euclid must have walked and contemplated while evolving his Elements, where the 70 rabbis laboriously translated the Pentateuch into Greek and where St. Mark preached the Gospel. Finally that part of me which is cataloger wanted to see the surroundings which met the eye of Callimachus in the third century B.C. when, though a poet and a philosopher, he also worked out a system of classifying and arranging the thousands of rolls which made him the most famous cataloger in history.

A great deal of imagination was required to try to recreate the original setting, but the incomparable Mediterranean sparkled in the morning sun, changed into iridescent hues of blue and green and reflected the violent colors of the sunset even as they had for the tired eyes of cataloger Callimachus. In one way this was an ideal starting point for a cataloger's pilgrimage. True to the heritage of Callimachus, I was to find that cataloging is still considered not only the most important but practically the only professional activity in libraries visited.

\section{Alexandria}

Farouk I. University is located in Alexandria and its Central Library was my first library call. While English is spoken wide- 
ly among the educated in Egypt (and among the guides and beggars in Cairo and Luxor) Alexandria is not mech of a tourist city so that requests for directions are not always understood. I took the precaution to have the hotel manager write down the name and address of the university in Arabic. This proved to be of no help to the taxi-driver, but he showed the slip to a policeman who could read and he gave the necessary directions. At the university, as at all others in Egypt at this time, there were many policemen standing about because of frequent student riots. One librarian complained that today's students were always striking about something -by such a method they had even succeeded in having tuition fees abolished. $\mathrm{He}$ was discouraged by their attitude and thought it much less scholarly than in his day (he was apparently about 40 years old).

The librarian of the Central Library, Burhan al-Din Zaki, is a thoroughly intelligent, ambitious and energetic individual. Everything was in great confusion that morning as they were moving into new quarters - a few rooms of an ugly, bare university building - but the librarian was as gracious and cordial as though I were the very person he had been hoping would arrive. His English was perfect, and he was anxious to show me his new quarters and to discuss library problems. Chief among these problems was the sudden growth of the library which was even more startling than the alarming rate of increase in American institutions. In 1942 the library had only 2000 volumes; in February 1948 it had 100,000, increased mainly by purchasing whole collections as, for example, that of the late Prince Ibrahim Hiliny, for which Zaki had helped prepare a printed catalog, and the German Library of Information. Since the university grants several kinds of advanced degrees, has a student body of 3000 and a faculty of
500 , most of the book use had fallen on the libraries of the different schools before the Central Library started to grow.

As is to be expected under such circumstances, the catalog department was a busy place with one trained cataloger and seven assistants, all men of course. The catalog was very businesslike - an alphabetic author list with a classified subject file arranged by the Dewey Decimal Classification. The latter had no index but as these files are kept in the catalog department their staff members help the readers use them.

There was also a reference room with the kind of collection that I was to find typical-a set of Larousse (Grand Dictionnaire), a set of La Grande Encyclopédie, an eleventh edition of the Encyclopaedia Britannica, a few miscellaneous items in European languages and several shelves of books in Arabic. These were presided over by a servant, seated on a raised platform which provided an unobstructed view of the room, who was clad in a long white garment colorfully set off by a wide red cummerbund and fez to match-the "reference attendant!"

Next day I went to the Library of the Faculty of Arts of the same Farouk I. University, located in another part of the city. When I arrived at the rather bleaklooking building I was halted by one of the usual blue-uniformed, red-fezzed policemen. Very courteous, as is universal among Egyptians, and very intelligent, although not understanding a word I said, he conducted me into the building to find an English-speaking student to be my guide.

We entered the reading room, quite small and with every one of the 40 seats occupied by students, including a few women. The librarian's office was behind this room, separated from it by a half-partition only. Here presided Mohamed Mahmoud ElSorougy who donned his fez in great haste and obvious embarrassment as I entered- 
it is a mark of courtesy to wear, not to remove, this jaunty headgear. His English was fluent and he was eager to show me his library and to ask questions-but not, of course, until after he had clapped his hands and a servant had appeared with the inevitable tiny cups of sweet black coffee which accompany every sort of transaction.

Here, as in most of the Egyptian university libraries, the books in European languages outnumber the Arabic language books by at least three to one, and are arranged by language. Of the 10,000 volumes (for Iooo students) most numerous were those in English, French and German. Few, indeed, were the American books. Everywhere there was this same lack and the same reasons given for it-American books have always been expensive and now "we have no dollars." Within each language books were arranged in chronological order. More modern was the catalog, made by the only other professional assistant in the library. He was a shy but intelligent little man who confided to me that he wanted to take some correspondence courses in library subjects, from an American institution, in order to advance himself. $\mathrm{He}$ had apparently caught the germ of the West.

\section{Cairo}

The libraries of Cairo have received more attention in literature than all the remaining libraries of the Near East put together. Mention will be made, therefore, of only a few things which I particularly enjoyed.

Mr. Kandil, the director-general of the National or Egyptian Library (formerly called the Khedivial Library), is a gracious, polished gentleman radiating his French education and his political background acquired at the State Education Department. The librarian is Mr. Omar, who made an extended visit to this country in the summer of 1948. Both of these officials were excited over an adventurous innovation they were about to launch-namely, the opening of two branch libraries that were to have open shelves. Small residential buildings had been secured, books selected and placed on the shelves, and suitable staff members delegated to take charge. Everything had been organized to admit the neighborhood readers, even the garden surrounding the quarters had been arranged for alfresco reading. And still the doors were not opened. What would happen? Would readers mutilate the books? (An attendant was stationed in each of the three or four tiny rooms.) Would readers walk off with the books? (A guard was placed at the door and a one-way traffic scheme worked out.) Would madame, the American librarian, be so kind as to accompany these gentlemen and examine the building, go over the plans of operation and decide whether such a daring program would succeed?

At the time my reaction, concealed of course, was just what yours probably is at this moment. Only after visits to a number of libraries in the Near East could I appreciate the pioneer spirit of these conscientious Cairo librarians, for the idea of open shelves is simply nonexistent. What makes this all the more striking is that almost all of the libraries of the American colleges and universities scattered through this part of the world have adopted the oriental policy of hands-off, rather than setting an American example of open shelf libraries. Recalling the history of the development of open access in this country one can understand the native librarian's cautious attitude. It is difficult to be sympathetic with the stand taken in the American institutions.

Among the books at the National Library the most impressive sight to western eyes is the extensive exhibition of Korans. Some 
of these are very old, written in the same monumental Kufic script which, carved in stone, decorates the mosques. One Koran is written entirely in gold, others are beautifully decorated in gold and shades of blue, the predominant color in mosques and books alike. Several of the Korans are of gigantic size, the largest one measuring $36^{\prime \prime} \times 46^{\prime \prime}$. This is probably the largest manuscript in the world, thus discrediting western book history in which the Codex Gigas ( $16^{\prime \prime} \times 32^{\prime \prime}$ ), in the University Library at Stockholm, is said to be the world's largest manuscript.

As in European collections the proportion of manuscripts to printed books is surprising to one used to American libraries. According to the director, the National Library has 750,000 volumes, about half of them in western languages, and 70,000 manuscripts. (This may be the place to state that none of the volume count of libraries, as given to me on the spot and set down immediately in a notebook, agrees with the figures in the $W$ orld of Learning, 1948.)

Throughout the Moslem world there are numerous theological colleges, attached to mosques, with book collections for their specialized field. Most famous of these mosques is the Al-Azhar in Cairo, housing a university founded in 970 A.D., and thus invalidating the claims of Bologna and other western institutions of being the oldest universities in the world. These madrassehs are noisy places as the boys chant their lessons aloud.

Strange as Egypt appeared to me at the time, in appraising it after seeing countries farther east, by contrast the Egyptians' attitude towards libraries and library service is far more like that of America than it is like that of their neighbors. Except for the handsome, black-tasseled red fez, the ever-present prayer beads and the sociable thimble-size cups of coffee, there is not so much difference between librarians there and here. They were sincere in their desire to give book service and to improve their libraries, and were as anxious as Americans to discuss library problems. They are pitifully aware of how far behind modern standards they are. They are not willing to keep on doing things as they have always been done, which is the traditional attitude of much of the Near East. They are so sure than American librarians have all the right answers. They turn to us so eagerly that we can only hope that we shall not fail them.

\section{Damascus}

By the time Damascus, oldest city in the world, is reached the West seems very far away. Appropriate to the antiquity of the city is the 700-year-old building which houses the Academy Library. Its neighbor on one side is the Great Mosque, where the head of St. John the Baptist is said to be buried, and not far away on the other side is the tomb of Saladin, the Mohammedan conquerer of Jerusalem in the twelfth century. One enters a quiet courtyard off of which open the rooms housing the library. The building is ancient and the collection contains many early manuscripts, but as a library, maintained for the members of the academy, it is only about 20 years old. In that time it has acquired about 6000 printed books and 4500 manuscripts. The books are arranged by size but the catalog is modern and is divided into three files-author, title and subject.

The manuscripts were in a separate room in which a king and his son lie buried. (Who they were I did not discover, but it is to be hoped that they were patrons of learning.) A small exhibition included a commentary on the Koran, written on paper and dated 266 A.H. (about 879 A.D.) This is thought to be the oldest Mohammedan manuscript written on paper in existence. Because of my interest in it the 
courteous attendant opened the case and insisted upon placing it in my hands so that I might examine it carefully.

\section{Teheran}

Not until Iran was reached did I see buildings which resembled libraries. The Persians dearly love imposing architecture and part of the late Reza Shah's program for modernizing his country was to widen a few of the narrow streets and to erect large buildings on them. In most other countries books are acquired and thus demand a building. But in Persia the National Library was both founded and built in 1937. It is situated in Teheran next to a magnificent museum which utilizes the most modern methods of lighting and display. The pair of buildings, with their beautifully landscaped grounds, form an impressive civic center. Like so much in Persia, however, there is more "front" than substance. The museum has a splendid collection reflecting the country's long history and artistic achievements, but the library has less than 50,000 volumes. In time, no doubt, the collection will grow up to the building. A few days later, driving from Persepolis to Shiraz, the car was halted over and over to let pass a nomad tribe moving from winter to summer quarters. As the camels, asses, sheep, tribesmen and their women and children streamed past, it was as though the pages of the Genesis had come to life and Abraham or Isaac or Jacob and his sons were driving their flocks before us. As long as there remain large sections of the country like this, it will not be surprising if the shelves of the large National Library fill slowly.

The Shah's collection of manuscripts is housed in a part of the Gulistan Palace, in the main part of which are displayed both the fabulous "Peacock Throne" and the enormous "Alabaster Throne" on which the monarchs are crowned. One room of the manuscript quarters is fitted like a private library and presided over by a bearded old scholar who obviously loves his treasures. Beautiful illuminated manuscripts were shown to us, all from the East-Egypt, Syria and Turkey, as well as Persia itself. It was a magnificent display of the finest of Islamic bookmaking, ancient and modern. Many volumes contained no text, being collections of miniatures only. Others existed as specimens of fine calligraphy, ever a highly cultivated and admired branch of art in Persia and used often in ornamentation of buildings as well as of books. Perhaps some day these handsome volumes will become a part of the National Library even as a comparable collection of western manuscripts, once the property of English kings, is now the Royal Collection in the British Museum.

\section{Meshed}

Unique among cities is Meshed, holy city of Persia and place of pilgrimage for members of the Shia sect of the Mohammedans, to some of whom it is more sacred than Mecca. The shrine built over and around the tomb of Imam Reza is also the burial place of his eighth-century contemporary, Haroun al-Raschid, of Arabian Nights fame. From the air, as the plane descends slowly to the bleak, desert airport, the extensive shrine buildings, with one gleaming gold dome and minaret and another of bright turquoise blue, dominate the city. The shrine buildings are enclosed by a high wall and guards are on constant duty in the watch towers. One of these buildings contains the tomb, housed in a small richly decorated room. One of the doors to this room is of silver, the other of gold. Both are well worn from the pious kisses of devout pilgrimages.

Entrance to the shrine is absolutely forbidden to all but Moslems (so that I visited it one night disguised in an all-con- 
cealing chadur) but the museum and the library are open to all. They are both housed in one imposing new building near the shrine but are outside its enclosing and forbidding walls. The librarian's office makes you think that you are indeed in the land of the Arabian Nights. It is a spacious, airy room, much larger than the reading room and very nearly as commodious as the room housing the books. Luxuriously furnished, only its massive desk gives the room an official appearance. Every inch of floor space is covered by dozens of handwoven Persian rugs, large and small and with a brilliant variety of colors and designs. The librarian presiding over this splendor knew no European languages, so we held a three-cornered conversation with my Persian-speaking American hostess acting as interpreter.

The Shrine Library was founded in the fifteenth century. It is open to all and acquires books in all fields of knowledge, mainly in Persian or Arabic as befits the needs of its clientele. The library contains 24,000 volumes of which more than a third are manuscripts, some of these being of great beauty and great antiquity. There is, of course, no open access to the shelves but printed books are circulated if the library has two copies so that one can always be had in the Library. It is, in fact, their policy to secure duplicates if possible, as otherwise a book cannot be circulated.

The small reading room had but one long table. On the shelves, in addition to a few Arabic and Persian reference books, there were the usual La Grande, Larousse and Britannica! One of the attendants took us through the "stacks" and the books have as luxurious housing as the librarian. Both floors, lower for printed books and upper for manuscripts, were completely covered with rugs on which one's feet sank in soundless comfort making "silence" signs unnecessary. Books were kept in hand- made wooden cases and were carefully protected by glass doors - a precaution against the swirling yellow dust of the region not deemed necessary for meat and other foods exposed in the open markets nor for the sad, fly-covered naked infants asleep in the streets outside.

Then followed a tour of the exhibition room, opened only on special occasions. My visit coincided, fortunately, with that of the prime minister from Iraq. The Shrine Library contains more than 1000 manuscripts of the Koran and some of the most magnificent of these were on display, including the one which has been called the most beautiful book in the world. Each page contains only a few lines of careful writing, executed either on a gold background or framed in gold with delicate gilt scrolls wandering between the lines. These writing panels are set in wide decorative borders of intricate design, a different pattern on each of the book's I 200 pages. Any pair of facing pages is a masterpiece of lovely color and graceful line. To view page after page is dazzling. While this Koran was the most elaborate, dozens of others had individual pages which often rivalled this one in beauty.

As calligraphy has ever been a highly respected art in the East many volumes carry the scribe's name and date. One of these has an association which makes it of interest to a westerner. The colophon states that the Koran was written by Ibrahim Sultan who was the son of Gobar Shad, the widow of Shah Rukh, son of Tamerlane.

Not all the library's treasures were of a religious nature. Also on display was a fine eleventh-century paper copy of the De Materia Medica of the Greek physician, Dioscorides. Although written in Arabic, its numerous water color paintings of the plants and animals described were very similar to those in the Pierpont Morgan's tenth-century vellum manuscript of the 
same work, but in Greek. I was free to examine page after page. It so happened that this was the last book in the last library that I visited in Persia. Here in this most fanatical and out-of-the-way city in the Middle East, I was more at home for the moment than I had been in the whole trip. Imagination carried me back to the Morgan Library and I saw again the pages of their

\section{Dioscorides.}

If in this account there has been more of books than of libraries, it is due in part, at least, to the fact that except for Egypt a library is looked upon much less as an institution to disseminate information, than as an organization to collect and catalog books. These are to be used, yes, but above all to be preserved.

\section{Research Libraries in Germany}

\section{(Continued from page 380 )}

the last. Besides those books which prove to have been instruments of Nazi propaganda, there are many, by apparently nonpolitical authors which, when carefully examined, show the infiltration of Hitler's tenets. One of the most effective methods of the Nazi party was to camouflage propaganda in this way, and many authors either consciously or unconsciously helped in this campaign. ${ }^{4}$ It is impossible to destroy all these books, but they present a problem and even a danger as long as great parts of the German population still incline to nationalism and antisemitism. In the postwar publications of German librarians these problems have not been touched any more than other educational and political problems. This apparent oversight has its source in the tradition of German librarianship and the training of librarians. The fields covered in the United States by the duties of the "readers' adviser" are almost unknown in Germany.

\footnotetext{
${ }^{4}$ Lehmann-Haupt, Hellmut. "What the Nazis Did to Children's Books." The Horn Book Magazine, 25:220-230, May-June 1949.
}

Book selection and annotation, display of instructive and valuable books, and personal advice to readers are not to be found in the research libraries. This is all the more unfortunate since, in Germany, research libraries also fulfil the functions of public libraries. The so-called "volksbuechereien" are not the equivalent of public libraries and have only small book collections selected for uneducated readers. The gap between the professional librarian working in research libraries and the librarian of "volksbuechereien" who, indeed, performed some educational work, was always great and does not seem to have diminished. The professional librarian did not take into consideration that he too had educational tasks and that the adult reader needed his guidance. The reorganization of the libraries, so well performed in many respects, has not balanced this lack in German librarianship-a lack which may perhaps prove more disastrous for German culture than the loss of books. 